\title{
From ecosystems to human welfare: the role and conservation of biodiversity
}

\author{
Zhenguo Zhang $^{1^{*}}$ (D) Jun Zhou ${ }^{1}$
}

${ }^{1}$ Institute of Biomedical Sciences, College of Life Sciences, Key Laboratory of Animal Resistance Biology of Shandong Province, Shandong Normal University (SDNU), Jinan, 250014, China. E-mail: zhangzhenguo201@163.com. "Corresponding author.

\begin{abstract}
Biodiversity plays a key role in human welfare by providing agricultural, economic, and health benefits. However, following the industrial revolution, the rapid expansion of the human population and subsequent economic activities have caused a dramatic loss in global biodiversity, resulting in significant disturbances to ecosystems and our own living conditions. Accordingly, the conservation of biodiversity has become one of the most important challenges for humanity. The vast numbers of plants, animals, and microorganisms, the enormous genetic diversity of these species and the different ecosystems to which these organisms belong are all part of a biologically diverse planet. A substantial proportion of the world's biodiversity has been destroyed, this loss is a catastrophe for all living species, including humans. Fortunately, we are working to remedy the destruction of our ecosystems. Herein, we summarized the discovery and development of biodiversity as a field of study and discuss the importance of the genetic and metabolite diversity. We proposed potential solutions to the loss of biodiversity with the aim of facilitating further exploration and identification of biodiversity, contributing for human welfare through the conservation of human habitats. Key words: biodiversity, ecosystem, agriculture, conservation, genetics, human welfare.
\end{abstract}

Dos ecossistemas ao bem estar humano: o papel e a conservação da biodiversidade

RESUMO: A biodiversidade desempenha um papel fundamental no bem-estar humano, proporcionando beneficios agricolas, economicos e de saúde. No entanto, após a revolução industrial, a rápida expansão da população humana e as subsequentes atividades econômicas provocaram uma perda drástica na biodiversidade global, resultando em perturbações significativas para os ecossistemas e nossas próprias condições de vida. Consequentemente, a conservação da biodiversidade tornou-se um dos desafios mais para a humanidade. O grande número de plantas, animais e microrganismos; a enorme diversidade genética destas espécies; e os diferentes ecossistemas aos quais pertencem esses organismos fazem parte de um planeta biologicamente diversificado. Uma proporção substancial da biodiversidade mundial foi destruída. Essa perda é uma catástrofe para todas as espécies vivas, incluindo os humanos. Felizmente, estamos trabalhando para remediar a destruição de nossos ecossistemas. Neste artigo resumimos a descoberta e o desenvolvimento da biodiversidade como área de estudo e discutimos a importância da análise funcional e metabólica. Propomos soluções potenciais para a perda de biodiversidade com o objetivo de facilitar a exploração e identificação da biodiversidade, contribuindo para o bem-estar da humanidade através da conservação dos habitats da nossa espécie.

Palavras-chave: biodiversidade, ecossistemas, agricultura, conservação, genética, bem estar humano.

\section{INTRODUCTION}

The wide range of Earth's biological variety is commonly referred to as biodiversity, which is the synthesis of the ecological complex formed by organisms and their environments and related ecological processes, including animals, plants, microorganisms and the genes they possess and the complex ecosystem formed by them and their living environment, including species diversity, genetic diversity and ecosystem diversity (PRIMACK, 2006). Species diversity refers to the richness of species on the earth, such as animals, plants and microorganisms. Genetic diversity mainly refers to the variation of genes within a species, including the genetic variation between significantly different species and within the same population. The diversity of ecosystem mainly refers to the diversity of ecosystem composition, function and various ecological processes on the earth. A rich assortment of species contributes to the function and stability of an ecosystem (NAEEM et al., 1994; MCCANN, 2000), and genetic diversity is inherent in the myriad species of plants, animals, and fungi. Varied ecosystems, such as croplands (HOU et al., 2014a; AN et al., 2015; BAI et al., 2016; DENG et al., 2016; CAO et al., 2017), saline-alkali soils (CHEN et al., 2010; DING et al., 2010; HAN et al., 2011; HAN et al., 2012; CHENG et al., 2014; DENG et al., 2015; FENG et al., 2015; GUO et al., 2015a; CHEN et al., 2016), rainforests(ZHANG \& LI, 2017), 
and coral reefs (WANG et al., 2015a; WANG et al., 2017a), are also part of a biologically diverse earth. As MA (Millennium Ecosystem Assessment) mentioned, ecosystem provide a state-of-the-art scientific appraisal of the condition and trends in the world's ecosystems and the services they provide (such as clean water, food, forage, forest products, biomass fuels, flood control and natural resources). Ecosystems also perform fundamental life support services, which include the regulation of climate, regeneration of soil fertility, and production and maintenance of biodiversity, mitigation of floods, drought, erosive forces of wind and rain. Biodiversity boosts an ecosystem's productivity because each species, regardless of size, plays a vital role in maintaining the overall fitness of the ecosystem (LIANG et al., 2010; HUANG et al., 2013; HE et al., 2016a; XIE \& ZHOU, 2017). For example, a wider array of plant species means a greater variety of crops(ZHAO et al., 2010a; LIU et al., 2013; WANG et al., 2014a; AN et al., 2015; DENG et al., 2016), and healthy ecosystems can better withstand and recover from a variety of disturbances(SONG \& WANG, 2015). Additionally, greater species diversity ensures natural sustainability for all life forms (YUAN et al., 2013a).

Biodiversity contributes directly (through provisioning, regulating, and cultural ecosystem services) and indirectly (through supporting ecosystem services) to many constituents of human well-being, including security, basic material for a good life, health, good social relations, and freedom of choice and action. Many people have benefited over the last century from the conversion of natural ecosystems to human-dominated ecosystems and the exploitation of biodiversity. At the same time, however, these losses in biodiversity and changes in ecosystem services have caused some people to experience declining well-being, with poverty in some social groups being exacerbated.

Herein, we review selected publications relevant to biodiversity with the goal of providing future directions aiming to maintain this important global resource. While humans may dominate this planet, we still need to conserve biodiversity in our world.

\section{Species diversity}

Biodiversity emphasizes the importance and multi-disciplinary significance of systematics by providing a descriptive taxonomic classification for the diversity of organisms. The basis of biodiversity is addressed directly, and indirectly, through studies of taxonomic relationships (YUAN et al., 2013a;
GAO et al., 2016) and of growth (ZHAO et al., 2010a; ZHAO et al., 2011a; FENG et al., 2014a; ZHOU et al., 2014b), form (YU et al., 2012; CHEN et al., 2016), adaptation(YU et al., 2012; LIU et al., 2013; SONG et al., 2017) and function (LI et al., 2010; KONG et al., 2011; DENG et al., 2015; FU et al., 2015; ZHANG et al., 2016) of organisms. Additionally, analysis and synthesis of biodiversity patterns in time and space, especially with respect to environmental and human factors, and application of the theories and methodologies associated with conservation biology are essential to understanding the factors contributing to the rich array of organisms within an ecosystem (YUAN et al., 2013a; GAO et al., 2015a; XIE \& ZHOU, 2017; ZHANG et al., 2017b). Taxonomic classifications of biodiversity provide data for understanding the origin and history of diversification of life on Earth, while simultaneously gathering scientific evidence to inform decisions related to conservation and resource management. Over the past decade, many new species, mainly plants and animals, have been reported (DU et al., 2010; MA et al., 2010; SUN et al., 2010; WANG et al., 2010; ZHANG et al., 2010b; LU et al., 2011; TIAN et al., 2011; CHENG et al., 2012; GAO \& REN, 2012; LU et al., 2012; WANG et al., 2012; ZHANG et al., 2012; ZHAO et al., 2012; ZHOU et al., 2012; HU et al., 2013; LI et al., 2013c; LU et al., 2013; REN, 2013; REN \& KOU, 2013; WANG et al., 2013b; YUAN et al., 2013a; ZHANG et al., 2013b; ZHAO et al., 2013a; ZHAO et al., 2013b; HOU et al., 2014b; HU et al., 2014; REN, 2014; REN \& ZHAO, 2014; ZHAO et al., 2014b; ELLIS et al., 2015; LIU et al., 2015; REN, 2015; WANG et al., 2015a; WANG et al., 2015c; YUAN et al., 2015a; ZHANG et al., 2015a; ZHANG et al., 2015b; ZHAO et al., 2015; WANG et al., 2016; ZHAO et al., 2016d; ZHAO et al., 2016e; LIU \& YAN, 2017; REN, 2017; WANG et al., 2017a; ZHAO et al., 2017).

For the conservation of species diversity, we should establish professional conserved areas, mine some unknown species, and conserve them. This is a valuable asset for future human beings. At the same time, endangered species can be propagated through artificial breeding.

\section{Plant diversity and conservation}

China is one of the richest countries for plant diversity with approximately 33000 vascular plant species, ranking second in the world (HUANG, 2011). However, the plant diversity in China is increasingly threatened, with an estimated 40005000 plant species being threatened or on the verge 
of extinction, making China, proportionally, one of the highest priorities for global plant biodiversity conservation. Coming in the face of the current ecological crisis, it is timely that China has launched China's Strategy for Plant Conservation (CSPC). Plants from the Gramineae, including wheat, rice, corn and bamboo, are the most economically important of seed plants. This family provides the main source of human food and livestock feed, we need to conserve the ancestors of these crops. For example, super rice was bred from wild rice hybrids (YU et al., 1997). Additionally, these plants serve as a source of important raw materials for processing into consumable products, such as starch, sugar, wine, paper, textiles, and construction materials. .The classification of grasses is contentious due to the array of natural crosses that create vague boundaries between species and difficulty in establishing distinguishing traits. Therefore, phylogenetic studies of the Gramineaeare are very important for generating a clear taxonomic classification of this family (ZHAO et al., 2010a; GUO et al., 2015a; SONG \& WANG, 2015; YUAN et al., 2015b; DENG et al., 2016; ZHU et al., 2016a; KONG et al., 2017).

For plant diversity, we focus on tall plants such as angiosperms and gymnosperms; however, lower plants, such as mosses, they are relatively small and easily overlooked by researchers, but their role in the ecosystem is very important and deserves our attention.

\section{Animal diversity and conservation}

Species diversity is changing globally and locally, but the complexity of ecological communities hampers a general understanding of the consequences of animal species loss on ecosystem functioning (LETOURNEAU et al., 2009; SCHNEIDER et al., 2016). Insects are not only the most species-rich group on earth, but they also play crucial roles in the function of ecosystems and the global economy. Conservation of insect diversity is therefore of global importance. However, insects are often ignored in studies of biological diversity; for example, relationships between insect diversity, vegetation, or climate change remain unclear. Research and model approaches focusing on insect diversity patterns are widely lacking (YUAN et al., 2015b). Studies of the spatial distribution of different insect taxa are needed in order to understand the contribution of potential cross-taxon relationships to diversity patterns (LIU et al., 2015; LIU \& YAN, 2017). In addition, research aimed at insects studies (e.g., cockroaches) and at conservation of insects that function as bioindicators for environmental conditions and biodiversity (e.g., beetles and butterflies) is needed (HUANG et al., 2013; ZHANG et al., 2013a; ZHANG et al., 2014; HE et al., 2015). Relationship between insect and plant diversity has been examined in order to determine how environmental factors, such as changes in climatic conditions, affect this interaction (ZHANG \& LI, 2017). Based on these research areas, the future of local and global insect diversity patterns can be predicted by using long-term historical studies of climate and vegetation quality. This approach will also allow an investigation into the relationship between pest insects, their host plants, and their predators.

Worms are one of the most diverse taxa in the animal kingdom, with estimates ranging from 100,000 to 100 million different species (MAY, 1988; COOMANS, 2000). In past years, some new freeliving nematode species have been identified (WANG et al., 2015a; WANG et al., 2017a). Worms are used as an indicator species for biodiversity assessments and biomonitoring (ZHANG et al., 2014)(ZHANG et al., 2014)(ZHANG et al., 2014) (ZHANG et al., 2014) (ZHANG et al., 2014) (ZHANG et al., 2014) (ZHANG et al., 2014). Additionally, many nematodes have developed parasitic life styles that cause numerous human diseases and enormous financial losses in agricultural and livestock sectors. Worms have also been increasingly used as model organisms to study human disease (GAO et al., 2015a; GAO et al., 2016). The worm, Caenorhabditis elegans, has been widely used as model to study human diseases such as infertility and senility (DOONAN et al., 2008; CASADEVALL I SOLVAS et al., 2011; PINCUS et al., 2011; GAO et al., 2015a). C. elegans is small and easy to propagate in large numbers; additionally, these animals are amenable to biochemical and genetic manipulations because mutations are easily induced. Furthermore, as C. elegans is predominantly hermaphroditic, the worms can produce offspring with homozygous mutations at a particular allele through self-fertilization (SMOLIKOV et al., 2009; SCHILDPRUFERT et al., 2011; CAHOON \& HAWLEY, 2016; GEISINGER \& BENAVENTE, 2016).

Fish occupy a key position in the evolution of the innate and adaptive immune responses; therefore, there is great interest in understanding the similarities and differences between their immunological defense mechanisms and those of higher vertebrates. For example, the effects of dietary nutrients or additives on the functions of the fish immune system have been under active investigation since the 1980s. Study of innate immunity in fish has become increasingly common since the discovery that many of the innate immune system components 
and pathways in lower organisms are homologous to those in higher invertebrates (PLOUFFE et al., 2005; WANG et al., 2010; SUN et al., 2012; LI et al., 2013a; ROMBOUT et al., 2014; YANG et al., 2014; HE et al., 2015; SHAN et al., 2015; ZHU et al., 2016b; LI et al., 2017; ZHANG \& LI, 2017; SHAN et al., 2018).

Mice are an ideal model system for the study of human biology and disease because they are relatively easy to maintain, have a high reproductive rate, can be genetically manipulated, and have high degree of similarity to humans with regards to metabolic, physiological and pathological conditions (BLAKE et al., 2011; CUI et al., 2011; SUN et al., 2012; GUO et al., 2015b; LOU et al., 2015; YUAN et al., 2015b; MENG et al., 2016; LIU et al., 2017; YANG et al., 2017; DING et al., 2018). Additionally, mouse genome database includes a complete catalog of mouse genes as well as features that allow integrated access to genetic, genomic, and phenotypic information.

Although, urbanization is very rapid, we still have to pay attention to animal diversity in suburban and rural areas. Some field animals not only provide us with extra food, but also effectively maintain the ecological balance of nature. The reintroduction of the wolf in Yellowstone is very interesting because it shows the changes that happened after the reintroduction of this animal at the level of the whole ecosystem. Animals can provide ecosystem functioning and consequently for human welfare.

\section{Microorganism diversity and conservation}

The diversity-stability relationship has been a controversial topic in ecology since the 1950s. Natural ecosystems are significantly influenced by human activity, so it is necessary to explore the diversity-stability relationship in relation to environmental disturbance and loss of biodiversity (TILMAN, 1996). Studies on this have focused more on above-ground terrestrial ecosystem, and consequently below-ground ecosystem has tended to be neglected, especially with regard to soil microbial diversity and stability. However, soil microbial diversity is crucial to the maintenance of ecosystem functioning as soil microorganisms influence many ecosystem processes and drive biogeochemical cycles. One important aim of soil microbial diversity research is to clarify the responses of soil microorganisms to various environmental fluctuations, so as to predict ecosystem stability and ecological service function (MARTINY et al., 2006). Microorganisms, a large group of organisms, including bacteria, viruses, some fungi, and small protozoans, are important parts of ecosystems, and are essential to virtually all ecological processes such as the material cycle and energy transformation (PROSSER, 2002; KONOPKA, 2009). Microbial diversity mainly refers to microbial system classification, species quantity, species composition, etc. Microorganisms play important roles in various ecosystems and often impact human welfare. To date, the most metabolically versatile microorganisms are the purple non-sulfur bacteria, a group of an oxygenic photosynthetic microorganisms that, in the absence of light, can employ both aerobic and anaerobic respiration, and fermentation. Some bacteria play vital roles in host-defense; for example, a strain of bacteria reported in cockroach intestinal flora may provide the insect with resistance to infection with the entomopathogenic fungi, Beauveriabassiana (HUANG et al., 2013; LI et al., 2013a; ZHANG et al., 2013a; SHAN et al., 2015; ZHU et al., 2016b).Similar to living organisms, viruses exhibit heritable genetic variation and evolve; however, these organisms are parasites that depend entirely on the energy and metabolic systems of the host cell (PLOUFFE et al., 2005; LIANG et al., 2010; QI et al., 2010; YU et al., 2012; HE et al., 2016a; ZHU et al., 2016b).

Lichenization is one of the major lifestyles among Fungi. The currently recognized more than 19,000 species of lichen fungi make up $17 \%$ of the known 110,000 fungal species and $27 \%$ of the known Ascomycota (FEUERER \& HAWKSWORTH, 2007; LüCKING et al., 2017). Because lichens are highly sensitive to air pollution, changes in lichen diversity are used as indicators of environmental conditions; therefore, lichens have been widely utilized in air quality assessment and monitoring programs around the world (LLOP et al., 2012). Lichen diversity has been used as an indicator since the nineteenth century for monitoring the effects of air pollution in urban areas. The diversity of lichen species and the change in species quantity serves as one indicator of an ecosystem's diversity(DU et al., 2010; MA et al., 2010; SUN et al., 2010; WANG et al., 2010; ZHANG et al., 2010b; LU et al., 2011; TIAN et al., 2011; CHENG et al., 2012; GAO \& REN, 2012; LU et al., 2012; WANG et al., 2012; ZHANG et al., 2012; ZHAO et al., 2012; ZHOU et al., 2012; HU et al., 2013; LI et al., 2013c; LU et al., 2013; REN, 2013; REN \& KOU, 2013; WANG et al., 2013b; YUAN et al., 2013a; ZHAO et al., 2013a; ZHAO et al., 2013b; HOU et al., 2014b; HU et al., 2014; REN, 2014; REN \& ZHAO, 2014; ZHAO et al., 2014b; LIU et al., 2015; REN, 2015; WANG et al., 2015c; WANG et al., 2015d; ZHANG et al., 2015a; ZHANG et al., 2015b; ZHAO et al., 2015; WANG et al., 2016; ZHAO et al., 2016d; 
ZHAO et al., 2016e; REN, 2017; ZHAO et al., 2017). Therefore, accurate species identifications and proper taxonomic classification of lichens is necessary for effective characterization of biological diversity. With the increasing availability of molecular profiling and improvement of analytical methods, criteria used for delimiting species have changed dramatically over the last decades (DU et al., 2010; MA et al., 2010; SUN et al., 2010; WANG et al., 2010; ZHANG et al., 2010b; LU et al., 2011; TIAN et al., 2011; CHENG et al., 2012; GAO \& REN, 2012; LLOP et al., 2012; LU et al., 2012; WANG et al., 2012; ZHANG et al., 2012; ZHAO et al., 2012; ZHOU et al., 2012; HU et al., 2013; LI et al., 2013c; LU et al., 2013; REN, 2013; REN \& KOU, 2013; WANG et al., 2013b; YUAN et al., 2013a; ZHAO et al., 2013a; ZHAO et al., 2013b; HOU et al., 2014b; HU et al., 2014; REN, 2014; REN \& ZHAO, 2014; ZHAO et al., 2014b; LIU et al., 2015; REN, 2015; WANG et al., 2015c; ZHANG et al., 2015a; ZHANG et al., 2015b; ZHAO et al., 2015; WANG et al., 2016; ZHAO et al., 2016d; ZHAO et al., 2016e; REN, 2017; ZHAO et al., 2017).

Pollution can directly poison the microorganism, hinder the normal growth and development, cause the environment to change, cause the microorganism to lose the living environment, affect the structure, function and dynamics of each level of ecosystem, then cause the ecosystem to degenerate (BOLDT \& JACOBSEN, 2010; WASILKOWSKI et al., 2015). This results in a reduction at the genetic, population and ecosystem levels.

Molecular phylogenetic analysis plays a very important role in the study of microbial diversity, it enables the investigation of phylogenetic relationships among microorganisms in a manner that was not feasible through traditional microbiological methods. The phylogenetic diversity based on the comparative sequence analysis produced new insights into the biodiversity conservation. It provides a method for biodiversity judgment and a guideline for biodiversity conservation. Also, it produces the aim of conservation, which is to keep the phylogenetic information as much as possible (HE et al., 2016a; DU \& ZHOU, 2018).

The virgin forest is the main gene bank and source pool of microorganisms. Conserving the original forest also conserves the microbial resources themselves. In general, we don't know the distribution, type and use of microorganisms (it will not be fully understood after 100 years). The insurance method is based on different climate types, geological conditions, different ecological types and different vegetation types. Choose a representative original habitat and a unique original (some are not original) to conserve the environment from human activities. Unified planning, selecting typical areas under the premise of being small and precise, organizing multidisciplinary and batching in batches, using advanced means microbiological resource background survey, while preserving the isolated strain resources.

\section{Genetic diversity}

Genetic diversity usually refers to the genetic diversity within a species, that is, the sum of genetic variation between individuals within a species or within a population. Genetic diversity is one of the three forms of biodiversity recognized by the World Conservation Union that requires conservation (REED \& FRANKHAM, 2003). The need to conserve genetic diversity within populations is based on two arguments: the necessity of genetic diversity for evolution to occur, and the expected relationship between heterozygosity and population fitness. Because loss of genetic diversity is related to inbreeding, and inbreeding reduces reproductive fitness, a correlation is expected between heterozygosity and population fitness. Genetic diversity is the sum of different genes of all living organisms, including plants(WANG et al., 2013a; LI et al., 2015), animals (BLAKE et al., 2011), animals (GAO et al., 2015b; GAO et al., 2016), and microorganisms(ZHU et al., 2016b). Genetic diversity serves as a way for populations to adapt to changing environments, such as global warming (ZHAO et al., 2014a) and increased salinity (YU et al., 2012; LI et al., 2015; SONG \& WANG, 2015). Genotypic and phenotypic diversity has been reported in all species at the level of the organism, protein, and DNA. The importance of genetic diversity is two-fold. First, increased genetic diversity is directly attributed to the adaptive ability of a species(GUO et al., 2012a; YU et al., 2012; LIU et al., 2013; ROMBOUT et al., 2014; SONG et al., 2017); second, a populations' fitness is closely related to its level of heterozygosity, a common measure of genetic diversity. The best way to illustrate the importance of genetic diversity is to highlight the consequences produced by loss of genetic variation (ZHAO et al., 2012; SONG et al., 2017).

Genetic diversity plays a key role in a species' survival and adaptive ability. When a population's habitat changes, the population may need to adapt to survive; the ability of the population to adapt to the changing environment determines its success in coping with an environmental challenge (REED \& FRANKHAM, 2003). The more genetic 
diversity within a population, the greater is likelihood that the population will be able to adapt. Genetic diversity is essential for a species to evolve. When there is little genetic diversity within a species, successful reproduction becomes increasingly difficult and offspring are more likely to have health and fertility issues resulting from inbreeding. The vulnerability of a population to certain types of diseases can also increase with reduction in genetic diversity. Conservation of genetic diversity is especially important in large mammals due to their reduced population size as a result of human activities.

Genetic diversity has declined globally, particularly among domesticated species. Since 1960 there has been a fundamental shift in the pattern of intra-species diversity in farmers' fields and farming systems as a result of the "Green Revolution".

\section{Ecosystem diversity}

Ecosystem diversity refers to the degree of ecological diversity in a region, covering various existing ecosystems within the biosphere (such as forest ecosystem, grassland ecosystem), which are different biological ecological processes occurring in different physical backgrounds. An important function of the ecosystem is to provide ecosystem services (supporting, provisioning, regulating, and cultural services) to humans. These services are essential for human well-being. However, at present there are few studies that link changes in biodiversity with changes in ecosystem functioning to changes in human well-being. Conserving the Catskill watersheds that provide drinking water for New York City is one case where safeguarding ecosystem services paid a dividend of several billion dollars (PIRES, 2004).

\section{The importance of biodiversity for mankind Agricultural relevance}

A detailed knowledge of biodiversity has allowed farming systems to evolve since agriculture began approximately12, 000 years ago. When humans initially started farming, they used selective breeding to accumulate desirable traits within crops, while omitting the undesirable ones. Agricultural biodiversity (agrobiodiversity) is a fundamental feature of farming systems around the world. It encompasses many types of biological resources involved in agriculture(LI et al., 2010; QI et al., 2010; ZHAO et al., 2010a; KONG et al., 2011; WANG et al., 2011; ZHAO et al., 2011a; HAN et al., 2012; LIU et al., 2012; TANG et al., 2012; YU et al., 2012; ZHAO et al., 2012; GUO et al., 2013; LIU et al., 2013; WANG et al., 2013a; YANG et al.,
2013; HAN et al., 2014; HOU et al., 2014a; WANG et al., 2014a; WANG et al., 2014b; ZHOU et al., 2014b; AN et al., 2015; LI et al., 2015; BAI et al., 2016; DENG et al., 2016; HE et al., 2016b; KONG et al., 2016; YUAN et al., 2016b; ZHANG et al., 2016; ZHAO et al., 2016b; CAO et al., 2017; KONG et al., 2017; WANG et al., 2017b; WANG et al., 2017c; ZHANG et al., 2017a), including genetic resources, edible plants and crops (WANG et al., 2011; YU et al., 2012; ZHAO et al., 2012; WANG et al., 2014b; GUO et al., 2015a; DENG et al., 2016), and livestock. Additionally, 'wild' resources (e.g., species and other elements) of natural habitats and landscapes can provide ecosystem maintenance and services (e.g., pest control and stability) to agriculture. Although, humans consume approximately 7,000 species of plants, only 150 species are commercially important, and only 103 species contribute $90 \%$ of the world's food crops (LOBELL et al., 2011). Just three cropsrice (LIU et al., 2012; LIU et al., 2013; YANG et al., 2013; ZHOU et al., 2014b; BAI et al., 2016; HE et al., 2016b), wheat (DENG et al., 2016; KONG et al., 2017), and maize (ZHAO et al., 2010a; WANG et al., 2014a)—account for approximately $60 \%$ of the calories and $56 \%$ of the protein humans derive from plants. Reduction in diversity often increases crop vulnerability to climatic and other stresses, raises economic risks for individual farmers, and can undermine agricultural stability. Worldwide, there is a growing realization that biodiversity is fundamental to agricultural production and food security, as well as a valuable component of environmental conservation. Agrobiodiversity, includes not only the maintenance of a wide variety of species and genetic resources, but also the many ways in which farmers can exploit biological diversity to produce and manage crops, land, water, insects, and biota (YUAN et al., 2015a; YUAN et al., 2019). The concept of sustainability also includes habitats and species, outside of farming systems, that benefit agriculture and enhance the maintenance of a viable ecosystem. For example, agricultural pest populations could be maintained by providing a source of host plants for natural enemies and predators of these pests. Developments in agriculture over the last 30 years have brought significant increases in global crop production, partly as a result of cropland expansion, but also because of changing technologies. However, one of the main concerns in, and around, agricultural land has been the serious degradation of natural resources, including soil changes, water pollution, and loss of biodiversity. These effects can undermine crop productivity; therefore, agricultural ecosystem needs 
to be conserved (WANG et al., 2011; ZHAO et al., 2016d; ZHU et al., 2016b). Saline soil is one of the important factors in restricting agriculture production and improving living environment. With rapid growth of human population and the high-speed development of economic construction, the concomitant increase in saline-alkali soil has severely affected crop growth; crops are hard to grow in saline-alkali fields, exploitation and utilization of saline soil, collecting salt-tolerant plants resources and mastering the plant salt resistance physiology and mechanism has become one of the important tasks of researchers (SONG et al., 2011; SONG \& WANG, 2015; SONG et al., 2016; SONG et al., 2017). Limonium bicolor and Suaeda salsa are halophytic species of flowering plants that thrive in saline-alkali soil. While the molecular mechanisms of resistance are poorly understood, these plants have developed efficient saline-alkali resistance systems that can potentially be used to determine the genetic factors contributing to saline-alkali tolerance(CHEN et al., 2010; DING et al., 2010; LI et al., 2010; QI et al., 2010; SUI et al., 2010; YANG et al., 2010; ZHANG et al., 2010a; ZHANG et al., 2010c; ZHAO et al., 2010b; HAN et al., 2011; KONG et al., 2011; PANG et al., 2011; SONG et al., 2011; WENG et al., 2011; ZHANG et al., 2011; ZHAO et al., 2011a; ZHAO et al., 2011b; GUO et al., 2012a; GUO et al., 2012b; HAN et al., 2012; HOU et al., 2012; LI et al., 2012; LIU et al., 2012; TANG et al., 2012; YU et al., 2012; CHEN et al., 2013; GUO et al., 2013; LI et al., 2013b; LIU et al., 2013; REN et al., 2013; SUN et al., 2013; YANG et al., 2013; YUAN et al., 2013b; CHENG et al., 2014; FENG et al., 2014b; HAN et al., 2014; HOU et al., 2014a; JIANG et al., 2014; LI et al., 2014; SHAO et al., 2014; SHEN et al., 2014; SUI \& HAN, 2014; WANG et al., 2014a; YUAN et al., 2014; ZHOU et al., 2014a; ZHOU et al., 2014b; AN et al., 2015; DENG et al., 2015; FENG et al., 2015; FU et al., 2015; GUO et al., 2015a; LI et al., 2015; MENG et al., 2015; SONG \& WANG, 2015; SUI, 2015; SUN et al., 2015; WANG et al., 2015b; YUAN et al., 2015b; BAI et al., 2016; CHEN et al., 2016; DENG et al., 2016; HE et al., 2016b; KONG et al., 2016; LIU et al., 2016; LU et al., 2016; SONG et al., 2016; XU et al., 2016; YUAN et al., 2016a; YUAN et al., 2016b; ZHANG et al., 2016; ZHAO et al., 2016a; ZHAO et al., 2016b; ZHAO et al., 2016c; ZHOU et al., 2016; CAO et al., 2017; SONG et al., 2017; WANG et al., 2017b; WANG et al., 2017c; ZHANG et al., 2017a; ZHENG et al., 2017). Until recently, Arabidopsis thaliana has been the preeminent model system used in plant molecular biology research; however, as a true glycophyte, little information regarding salt tolerance in plants can be obtained from the study of A. thaliana. Therefore, as a relative of A. thaliana, salt cress, Thellungillahalophila, is a potential model for the study of salinity tolerance (GUO et al., 2012b; CHEN et al., 2013; SUI \& HAN, 2014; LIU et al., 2016; WANG et al., 2017b).L. bicolor is a typical recreto halophyte with a multicellular salt gland structure that is suitable as a model system for the study of the salt glands in dicotyledons; this species is distributed in coastal and salinized area and is employed as a "pioneer plant" for utilizing and improving saline soils (DING et al., 2010; YUAN et al., 2013b; FENG et al., 2014b; YUAN et al., 2014; DENG et al., 2015; FENG et al., 2015; YUAN et al., 2015b; YUAN et al., 2016a; YUAN et al., 2016b).

\section{Causes leading to extinction}

Between $10 \%$ and $50 \%$ of well-studied higher taxonomic groups (mammals, birds, amphibians, conifers, and cycads) are currently threatened with extinction in accordance with IUCNWorld Conservation Union criteria for threats of extinction. In which, there are extrinsic and intrinsic factors, extrinsic factors and examples are shown as follows: habitat degradation (Aurochs in 1627, Caucasian Bison in1925, New Mexican Wolf in 1920, Barbary Lion in 1922 and Tasmanian Wolf in 1933), introduction of exotic species (Eichhornia crassipes in China), over-exploitation (hunting and fishing). Intrinsic factors include the following, inbreeding, genetic drift, reduction of effective population size. Over the past few hundred years, humans have increased species extinction rates by as much as 1,000 times background rates that were typical over Earth's history (PIMM \& BROWN, 2004).

\section{Biodiversity conservation}

Conserved areas are an extremely important part of programs to conserve biodiversity and ecosystems, especially for sensitive habitats. Conservation of wild animals and plants around the world is now mainly based on the in-situ and ex-situ conservation. It is of more practical significance to maintain the reproduction and evolution of organisms in the ecosystem, maintain material circulation and energy flow in the ecosystem, and maintain the ecosystem services and functions. It is the most effective measure for biodiversity conservation. Insitu conservation is also one of the important research fields and contents in conservation biology (FAZEY et al., 2005).The conservation of the Iberian lynx in the Iberian Peninsula, Panda in China have been 
proved that the improvement of habitat quality and comprehensive and detailed improvement of existing habitat can effectively conserve endangered animals. At the same time, the establishment of multiple conservation centers realized gene exchange and gene diversity conservation of different populations (FERRERAS, 2001; LU et al., 2012).

Conversely, due to the limitations of insitu conservation, some key wildlife conservation measures must be taken in order to conserve the wildlife effectively, expand the population scale and play its role in the economic and ecological fields. The reintroduction of the wolf in Yellowstone turned out to be a success, which is a very interesting example, because it shows the changes that happened after the reintroduction of this animal at the level of the whole ecosystem.

To achieve good conservation, the crucial step is to correctly identify and distinguish species, especially endangered and rare species that need to be conserved. Only when species are accurately divided and identified can it be determined whether an individual is in the same taxonomic unit as other individuals, which is very important for biodiversity conservation. For a long time in the past, species identification relied mainly on morphological identification. However, morphological identification is not a simple work, and the number of taxonomists is still shrinking year by year. The professionalism of morphological classification methods and the shortage of taxonomists are undoubtedly a challenge for biodiversity conservation. The DNA barcoding has unique advantages in expanding the range of research objects, especially for endangered species that cannot be shot or observed at close range. At the same time, DNA barcode technology is not affected by subjective judgment, which is conducive to the discovery of new or hidden species, rapid and accurate identification of species, formation of a unified identification standard, establishment of a database platform, and the communication with global network information, and the effective conservation of biodiversity.

\section{CONCLUSION}

Over the last decade, biodiversity conservation has become a topic of international conventions and a policy device employed in the environmental sector. National governments, state agencies, non-governmental organizations, local communities, schoolclubs, and individuals are becoming aware of biodiversity importance. However, the world's countries that are the richest in biodiversity are, at the same time, where biodiversity is under the most serious threat. The study of biodiversity is not an integrated science, for example, botanists and zoologists still study plants and animals independently of one another. Animal, plant and microbial diversity need to be examined together to gain a complete understanding of the relationship between diverse species. Additionally, increased research is needed to explore genetic and metabolic diversity. Finally, further study of genetic diversity and its link to human diseases will provide insights into disease prevention and therapy. Human should conserve biodiversity, for example, the consumption of goods, reducing the use of plastics, etc. The authors hold that a global biodiversity survey is a fundamental necessity and suggest a comprehensive investigation and evaluation of the factors contributing to biodiversity and the establishment of a biodiversity monitoring network system.

\section{ACKNOWLEDGMENTS}

The authors are grateful to Professor JINMIN GAO and XIN DU for helpful discussions and comments. This work was supported by Shandong Key Laboratory of Animal Resistance Biology Open fund (2017KF06) and the National Natural Science Foundation of China (31801137).

\section{DECLARATION OF CONFLICT OF INTERESTS}

The authors declared no potential conflicts of interest with respect to the research, authorship, and/or publication of this article.

\section{REFERENCES}

AN, J. et al. Cloning and expression analysis of four DELLA genes in peanut. Russian Journal Of Plant Physiology, v.62, n.1, p.116-126. 2015. Available from: <http://dx.doi: 10.1134/ s1021443715010021>. Accessed: Jan. 2015. doi: 10.1134/ s1021443715010021.

BAI, B. et al. OsBBX14 delays heading date by repressing florigen gene expression under long and short-day conditions in rice. Plant Science, v.247, p.25-34. 2016. Available from: <http:// dx.doi: 10.1016/j.plantsci.2016.02.017>. Accessed: Jun. 2016. doi: 10.1016/j.plantsci.2016.02.017.

BLAKE, J. A. et al. The Mouse Genome Database (MGD): premier model organism resource for mammalian genomics and genetics. Nucleic Acids Res, v.39, n.Database issue, p.D842-8. 2011. Available from: <http://dx.doi: 10.1093/nar/gkq1008>. Accessed: Jan. 2011. doi: 10.1093/nar/gkq1008.

BOLDT, T. S.; JACOBSEN, C. S. Different toxic effects of the sulfonylurea herbicides metsulfuron methyl, chlorsulfuron and thifensulfuron methyl on fluorescent pseudomonads isolated from an agricultural soil. Fems Microbiology Letters, v.161, n.1, p.2935. 2010. Available from: <http://dx.doi: 2010. doi. 
CAHOON, C. K.; HAWLEY, R. S. Regulating the construction and demolition of the synaptonemal complex. Nat Struct Mol Biol, v.23, n.5, p.369-77. 2016. Available from: <http://dx.doi: 10.1038/ nsmb.3208>. Accessed: May, 04, 2016. doi: 10.1038/nsmb.3208.

$\mathrm{CAO}, \mathrm{S}$. et al. Overexpression of Populus tomentosa cytosolic ascorbate peroxidase enhances abiotic stress tolerance in tobacco plants. Russian Journal Of Plant Physiology, v.64, n.2, p.224-234. 2017. Available from: <http://dx.doi: 10.1134/ s1021443717020029>. Accessed: Mar. 2017. doi: 10.1134/ s1021443717020029.

CASADEVALL I SOLVAS, $\mathrm{X}$. et al. High-throughput age synchronisation of Caenorhabditis elegans. Chem Commun (Camb), v.47, n.35, p.9801-3. 2011. Available from: <http:// dx.doi: 10.1039/c1cc14076k>. Accessed: Sep. 21, 2011. doi: $10.1039 / \mathrm{c} 1 \mathrm{cc} 14076 \mathrm{k}$

CHEN, M. et al. $\mathrm{NaCl}$ increases the activity of the plasma membrane H+-ATPase in C-3 halophyte Suaeda salsa callus. Acta Physiologiae Plantarum, v.32, n.1, p.27-36. 2010. Available from: $<$ http://dx.doi: 10.1007/s11738-009-0371-7>. Accessed: Jan. 2010. doi: $10.1007 / \mathrm{s} 11738-009-0371-7$.

CHEN, M. et al. Abscisic acid is involved in the response of Arabidopsis mutant sad2-1 to ultraviolet-B radiation by enhancing antioxidant enzymes. South African Journal Of Botany, v.85, p.79-86. 2013. Available from: <http://dx.doi: 10.1016/j. sajb.2012.11.006>. Accessed: Mar. 2013. doi: 10.1016/j. sajb.2012.11.006.

CHEN, T. S. et al. Nitric oxide participates in waterlogging tolerance through enhanced adventitious root formation in the euhalophyte Suaeda salsa. Functional Plant Biology, v.43, n.3, p.244-253. 2016. Available from: <http://dx.doi: 10.1071/ fp15120>. Accessed: 2016. doi: 10.1071/fp15120.

CHENG, S. et al. Salinity improves chilling resistance in Suaeda salsa. Acta Physiologiae Plantarum, v.36, n.7, p.1823-1830. 2014. Available from: <http://dx.doi: 10.1007/s11738-014-15553>. Accessed: Jul. 2014. doi: 10.1007/s11738-014-1555-3.

CHENG, Y. L. et al. Herpothallon weii, a new lichen from China. Mycotaxon, v.119, p.439-443. 2012. Available from: $<$ http://dx.doi: 10.5248/119.439>. Accessed: Jan-Mar. 2012. doi: $10.5248 / 119.439$

COOMANS, A. Nematode systematics: past, present and future. Nematology, v.2, n.1, p.3-7. 2000. Available from: <http://dx.doi: doi:https://doi.org/10.1163/156854100508845>. Accessed: 2000 doi: doi:https://doi.org/10.1163/156854100508845.

CUI, L. L. et al. Tumor necrosis factor alpha knockout increases fertility of mice. Theriogenology, v.75, n.5, p.867-876. 2011. Available from: <http://dx.doi: 10.1016/j. theriogenology.2010.10.029>. Accessed: Mar. 2011. doi: 10.1016/j.theriogenology.2010.10.029.

DENG, Y. Q. et al. Exogenous hydrogen sulfide alleviates salt stress in wheat seedlings by decreasing $\mathrm{Na}+$ content. Plant Growth Regulation, v.79, n.3, p.391-399. 2016. Available from: $<$ http://dx.doi: 10.1007/s10725-015-0143-x>. Accessed: Jul. 2016. doi: $10.1007 / \mathrm{s} 10725-015-0143-\mathrm{x}$

DENG, Y. Q. et al. Identification and functional analysis of the autofluorescent substance in Limonium bicolor salt glands. Plant
Physiology And Biochemistry, v.97, p.20-27. 2015. Available from: <http://dx.doi: 10.1016/j.plaphy.2015.09.007>. Accessed: Dec. 2015. doi: 10.1016/j.plaphy.2015.09.007.

DING, F. et al. Ca2+ significantly enhanced development and salt-secretion rate of salt glands of Limonium bicolor under $\mathrm{NaCl}$ treatment. South African Journal Of Botany, v.76, n.1, p.95-101. 2010. Available from: <http://dx.doi: 10.1016/j.sajb.2009.09.001>. Accessed: Jan. 2010. doi: 10.1016/j.sajb.2009.09.001.

DING, N. Z. et al. De novo synthesis of sphingolipids is essential for decidualization in mice. Theriogenology, v.106, p.227-236. 2018. Available from: <http://dx.doi: 10.1016/j. theriogenology.2017.09.036>. Accessed: Jan. 15, 2018. doi: 10.1016/j.theriogenology.2017.09.036.

DOONAN, R. et al. Against the oxidative damage theory of aging: superoxide dismutases protect against oxidative stress but have little or no effect on life span in Caenorhabditis elegans. Genes Dev, v.22, n.23, p.3236-41. 2008. Available from: <http://dx.doi: 10.1101/gad.504808>. Accessed: Dec. 01, 2008. doi: 10.1101/ $\operatorname{gad} .504808$.

DU, X.; ZHOU, J. Application of biosensors to detection of epidemic diseases in animals. Research in Veterinary Science, v.118, p.444-448. 2018. Available from: <http://dx.doi: 10.1016/j. rvsc.2018.04.011>. Accessed: Jun. 2018. doi: 10.1016/j. rvsc.2018.04.011.

DU, Y. D. et al. Three new records of brown parmelioid lichens from the Tibetan Plateau. Mycotaxon, v.111, p.283-286. 2010. Available from: $<\mathrm{http}: / / \mathrm{dx}$.doi: 10.5248/111.283>. Accessed: JanMar. 2010. doi: 10.5248/111.283.

ELLIS, L. T. et al. New national and regional bryophyte records, 44. Journal Of Bryology, v.37, n.3, p.228-241. 2015. Available from: <http://dx.doi: $10.1179 / 1743282015 y .0000000014>$. Accessed: Sep. 2015. doi: 10.1179/1743282015y.0000000014.

FAZEY, I. et al. What do conservation biologists publish? Biological Conservation, v.124, n.1, p.63-73. 2005. Available from: $<$ http://dx.doi: 2005. doi.

FENG, Z. T. et al. Effects of $\mathrm{NaCl}$ stress on the growth and photosynthetic characteristics of Ulmus pumila L. seedlings in sand culture. Photosynthetica, v.52, n.2, p.313-320. 2014a. Available from: <http://dx.doi: 10.1007/s11099-014-0032-y>. Accessed: Jun. 2014a. doi: 10.1007/s11099-014-0032-y.

FENG, Z. T. et al. $\mathrm{K}+$ accumulation in the cytoplasm and nucleus of the salt gland cells of Limonium bicolor accompanies increased rates of salt secretion under $\mathrm{NaCl}$ treatment using NanoSIMS. Plant Science, v.238, p.286-296. 2015. Available from: <http:// dx.doi: 10.1016/j.plantsci.2015.06.021>. Accessed: Sep. 2015. doi: 10.1016/j.plantsci.2015.06.021.

FENG, Z. T. et al. Study on pathway and characteristics of ion secretion of salt glands of Limonium bicolor. Acta Physiologiae Plantarum, v.36, n.10, p.2729-2741. 2014b. Available from: $<$ http://dx.doi: 10.1007/s11738-014-1644-3>. Accessed: Oct. 2014b. doi: 10.1007/s11738-014-1644-3.

FERRERAS, P. Landscape structure and asymmetrical inter-patch connectivity in a metapopulation of the endangered Iberian lynx. Biological Conservation, v.99, n.1, p.125-136. 2001. Available from: <http://dx.doi: 2001. doi. 
FEUERER, T.; HAWKSWORTH, D. L. Biodiversity of lichens, including a world-wide analysis of checklist data based on Takhtajan's floristic regions. Biodiversity \& Conservation, v.16, n.1, p.85-98. 2007. Available from: <http://dx.doi: 2007. doi.

FU, C. et al. AtFes1A is Essential for Highly Efficient Molecular Chaperone Function in Arabidopsis. Journal Of Plant Biology, v.58, n.6, p.366-373. 2015. Available from: <http://dx.doi: 10.1007/s12374-015-0181-y>. Accessed: Dec. 2015. doi: 10.1007/ s12374-015-0181-y.

GAO, J. et al. N-terminal acetylation promotes synaptonemal complex assembly in C. elegans. Genes Dev, v.30, n.21, p.2404-2416. 2016. Available from: <http://dx.doi: 10.1101/ gad.277350.116>. Accessed: Nov. 01, 2016. doi: 10.1101/ gad.277350.116.

GAO, J. et al. NatB domain-containing CRA-1 antagonizes hydrolase ACER-1 linking acetyl-CoA metabolism to the initiation of recombination during C. elegans meiosis. PLoS Genet, v.11, n.3, p.e1005029. 2015a. Available from: <http://dx.doi: 10.1371/ journal.pgen.1005029>. Accessed: Mar. 2015a. doi: 10.1371/ journal.pgen.1005029.

GAO, J. et al. NatB domain-containing CRA-1 antagonizes hydrolase ACER-1 linking acetyl-CoA metabolism to the initiation of recombination during C. elegans meiosis. Plos Genetics, v.11, n.3, p.e1005029. 2015b. Available from: <http://dx.doi: 2015b. doi.

GAO, T. L.; REN, Q. New records of Ochrolechia and Placopsis from the Hengduan Mountains, China. Mycotaxon, v.122, p.461466. 2012. Available from: <http://dx.doi: 10.5248/122.461>. Accessed: Oct-Dec, 2012. doi: 10.5248/122.461.

GEISINGER, A.; BENAVENTE, R. Mutations in Genes Coding for Synaptonemal Complex Proteins and Their Impact on Human Fertility. Cytogenet Genome Res, v.150, n.2, p.77-85. 2016. Available from: <http://dx.doi: 10.1159/000453344>. Accessed: 2016. doi: $10.1159 / 000453344$.

GUO, F. D. et al. Induced Expression of AtLEC1 and AtLEC2 Differentially Promotes Somatic Embryogenesis in Transgenic Tobacco Plants. Plos One, v.8, n.8. 2013. Available from: <http:// dx.doi: 10.1371/journal.pone.0071714>. Accessed: Aug, 2013. doi: 10.1371/journal.pone.0071714.

GUO, J. R. et al. Sodium chloride improves seed vigour of the euhalophyte Suaeda salsa. Seed Science Research, v.25, n.3, p.335-344. 2015a. Available from: <http://dx.doi: 10.1017/ s0960258515000239>. Accessed: Sep. 2015a. doi: 10.1017/ s0960258515000239.

GUO, T. et al. Low-density lipoprotein receptor affects the fertility of female mice. Reproduction Fertility And Development, v.27, n.8, p.1222-1232. 2015b. Available from: <http://dx.doi: 10.1071/ rd13436>. Accessed: 2015b. doi: 10.1071/rd13436.

GUO, Y. H. et al. Thellungilla halophila is more adaptive to salinity than Arabidopsis thaliana at stages of seed germination and seedling establishment. Acta Physiologiae Plantarum, v.34, n.4, p.1287-1294. 2012a. Available from: <http://dx.doi: 10.1007/ s11738-012-0925-y>. Accessed: Jul. 2012a. doi: 10.1007/s11738012-0925-y.

GUO, Y. H. et al. Effects of seed vernalisation and photoperiod on flowering induction in the halophyte Thellungiella halophila.
Australian Journal Of Botany, v.60, n.8, p.743-748. $2012 \mathrm{~b}$. Available from: <http://dx.doi: 10.1071/bt12180>. Accessed: 2012b. doi: $10.1071 / \mathrm{bt} 12180$.

HAN, G. L. et al. The CCCH zinc finger protein gene AtZFP1 improves salt resistance in Arabidopsis thaliana. Plant Molecular Biology, v.86, n.3, p.237-253. 2014. Available from: <http:// dx.doi: 10.1007/s11103-014-0226-5>. Accessed: Oct. 2014. doi: 10.1007/s11103-014-0226-5.

HAN, N. et al. Expression of a Suaeda salsa Vacuolar $\mathrm{H}+/ \mathrm{Ca} 2+$ Transporter Gene in Arabidopsis Contributes to Physiological Changes in Salinity. Plant Molecular Biology Reporter, v.30, n.2, p.470-477. 2012. Available from: <http://dx.doi: 10.1007/s11105-0110353-y>. Accessed: Apr. 2012. doi: 10.1007/s11105-011-0353-y.

HAN, N. et al. Cloning and Characterization of a $\mathrm{Ca} 2+/ \mathrm{H}+$ Antiporter from Halophyte Suaeda salsa L. Plant Molecular Biology Reporter, v.29, n.2, p.449-457. 2011. Available from: <http://dx.doi: 10.1007/s11105-010-0244-7>. Accessed: Jun. 2011. doi: $10.1007 / \mathrm{s} 11105-010-0244-7$.

HE, C. Q. et al. New genetic mechanism, origin and population dynamic of bovine ephemeral fever virus. Veterinary Microbiology, v.182, p.50-56. 2016a. Available from: <http:// dx.doi: 10.1016/j.vetmic.2015.10.029>. Accessed: Jan. 2016a. doi: 10.1016/j.vetmic.2015.10.029.

$\mathrm{HE}, \mathrm{X}$. et al. Identification of novel microtubule-binding proteins by taxol-mediated microtubule stabilization and mass spectrometry analysis. Thorac Cancer, v.6, n.5, p.649-54. 2015. Available from: $<$ http://dx.doi: 10.1111/1759-7714.12284>. Accessed: Sep. 2015. doi: $10.1111 / 1759-7714.12284$.

HE, Y. A. et al. Phytochrome B Negatively Affects Cold Tolerance by Regulating OsDREB1 Gene Expression through Phytochrome Interacting Factor-Like Protein OsPIL16 in Rice. Frontiers In Plant Science, v.7. 2016b. Available from: <http://dx.doi: 10.3389/fpls.2016.01963>. Accessed: Dec. 2016b. doi: 10.3389/ fpls.2016.01963.

HOU, L. et al. Construction of Stress Responsive Synthetic Promoters and Analysis of Their Activity in Transgenic Arabidopsis thaliana. Plant Molecular Biology Reporter, v.30, n.6, p.14961506. 2012. Available from: <http://dx.doi: $10.1007 / \mathrm{s} 11105-012-$ 0464-0>. Accessed: Dec. 2012. doi: 10.1007/s11105-012-0464-0.

HOU, L. et al. Identification and expression analysis of genes responsive to drought stress in peanut. Russian Journal Of Plant Physiology, v.61, n.6, p.842-852. 2014a. Available from: <http:// dx.doi: 10.1134/s1021443714060089>. Accessed: Nov. 2014a. doi: $10.1134 / \mathrm{s} 1021443714060089$.

HOU, X. J. et al. Three new records of aspicilioid lichens from China. Telopea, v.16, p.159-163. 2014b. Available from: <http:// dx.doi: 10.7751/telopea20147957>. Accessed: 2014b. doi: 10.7751/telopea20147957.

HU, L. et al. Two Ropalospora lichens new to mainland China Mycotaxon, v.123, p.439-444. 2013. Available from: <http:// dx.doi: 10.5248/123.439>. Accessed: Jan-Mar. 2013. doi: $10.5248 / 123.439$

HU, L. et al. Four lecideoid lichens new to China. Mycotaxon, v.128, p.83-91.2014. Available from: <http://dx.doi: $10.5248 / 128>$. Accessed: Apr-Jun. 2014. doi: 10.5248/128. 
HUANG, H. Plant diversity and conservation in China: planning a strategic bioresource for a sustainable future. Botanical Journal of the Linnean Society, v.166, n.3, p.282-300. 2011. Available from: $<$ http://dx.doi: 2011. doi.

HUANG, Y. H. et al. The Identification of a Bacterial Strain BGI1 Isolated From the Intestinal Flora of Blattella Germanica, and Its Anti-Entomopathogenic Fungi Activity. Journal Of Economic Entomology, v.106, n.1, p.43-49. 2013. Available from: <http:// dx.doi: 10.1603/ec12120>. Accessed: Feb. 2013. doi: 10.1603/ ec12120.

JIANG, C. Y. et al. Increased expression of mitochondria-localized carbonic anhydrase activity resulted in an increased biomass accumulation in Arabidopsis thaliana. Journal Of Plant Biology, v.57, n.6, p.366-374. 2014. Available from: <http://dx.doi: $10.1007 /$ s12374-014-0330-8>. Accessed: Dec. 2014. doi: 10.1007/s12374014-0330-8.

KONG, L. A. et al. Excessive nitrogen application dampens antioxidant capacity and grain filling in wheat as revealed by metabolic and physiological analyses. Scientific Reports, v.7. 2017. Available from: <http://dx.doi: 10.1038/srep43363>. Accessed: Feb. 2017. doi: 10.1038/srep43363.

KONG, X. Q. et al. Cloning and functional characterization of a cation-chloride cotransporter gene OsCCC1. Plant Molecular Biology, v.75, n.6, p.567-578. 2011. Available from: <http:// dx.doi: 10.1007/s11103-011-9744-6>. Accessed: Apr. 2011. doi: 10.1007/s11103-011-9744-6.

KONG, X. Q. et al. Exogenous nitric oxide delays salt-induced leaf senescence in cotton (Gossypium hirsutum L.). Acta Physiologiae Plantarum, v.38, n.3. 2016. Available from: <http://dx.doi: 10.1007/s11738-016-2079-9>. Accessed: Mar. 2016. doi: 10.1007/ s11738-016-2079-9.

KONOPKA, A. What is microbial community ecology? Isme Journal, v.3, n.11, p.1223. 2009. Available from: <http://dx.doi: 2009. doi.

LETOURNEAU, D. K. et al. Effects of Natural Enemy Biodiversity on the Suppression of Arthropod Herbivores in Terrestrial Ecosystems. Annual Review of Ecology Evolution \& Systematics, v.40, n.1, p.573-592. 2009. Available from: <http:// dx.doi: 2009. doi.

LI, H. et al. Molecular characterization of a fish-specific toll-like receptor 22 (TLR22) gene from common carp (Cyprinus carpio L.): Evolutionary relationship and induced expression upon immune stimulants. Fish \& Shellfish Immunology, v.63, p.74-86. 2017. Available from: <http://dx.doi: 10.1016/j.fsi.2017.02.009>. Accessed: Apr. 2017. doi: 10.1016/j.fsi.2017.02.009.

LI, H. et al. Molecular characterization of hepcidin gene in common carp (Cyprinus carpio L.) and its expression pattern responding to bacterial challenge. Fish \& Shellfish Immunology, v.35, n.3, p.1030-1038. 2013a. Available from: <http://dx.doi: 10.1016/j.fsi.2013.07.001>. Accessed: Sep. 2013a. doi: 10.1016/j. fsi.2013.07.001.

LI, K. et al. Overexpression of Suaeda salsa stroma ascorbate peroxidase in Arabidopsis chloroplasts enhances salt tolerance of plants. South African Journal Of Botany, v.78, p.235-245. 2012. Available from: <http://dx.doi: 10.1016/j.sajb.2011.09.006>. Accessed: Jan. 2012. doi: 10.1016/j.sajb.2011.09.006.
LI, S. P. et al. EXO70A1-Mediated Vesicle Trafficking Is Critical for Tracheary Element Development in Arabidopsis. Plant Cell, v. 25 , n.5, p.1774-1786. 2013b. Available from: <http://dx.doi: 10.1105/tpc.113.112144>. Accessed: May, 2013b. doi: 10.1105/ tpc.113.112144.

LI, S. P. et al. Expression and Functional Analyses of EXO70 Genes in Arabidopsis Implicate Their Roles in Regulating Cell TypeSpecific Exocytosis. Plant Physiology, v.154, n.4, p.1819-1830. 2010. Available from: <http://dx.doi: 10.1104/pp.110.164178>. Accessed: Dec. 2010. doi: 10.1104/pp.110.164178

LI, S. X. et al. New records of Aspicilia species from China. Mycotaxon, v.126, p.91-96. 2013c. Available from: $<$ http://dx.doi: 10.5248/126.91>. Accessed: Oct-Dec. 2013c. doi: 10.5248/126.91.

LI, Y. Y. et al. Developmental Genetic Mechanisms of C-4 Syndrome Based on Transcriptome Analysis of C-3 Cotyledons and C-4 Assimilating Shoots in Haloxylon ammodendron. Plos One, v.10, n.2. 2015. Available from: <http://dx.doi: 10.1371/ journal.pone.0117175>. Accessed: Feb. 2015. doi: 10.1371/ journal.pone. 0117175 .

LI, Y. Y. et al. Was low $\mathrm{CO} 2$ a driving force of C-4 evolution: Arabidopsis responses to long-term low CO2 stress. Journal Of Experimental Botany, v.65, n.13, p.3657-3667. 2014. Available from: <http://dx.doi: 10.1093/jxb/eru193>. Accessed: Jul. 2014. doi: $10.1093 / \mathrm{jxb} / \mathrm{eru} 193$.

LIANG, J. W. et al. Selection characterization on overlapping reading frame of multiple-protein-encoding $\mathrm{P}$ gene in Newcastle disease virus. Veterinary Microbiology, v.144, n.3-4, p.257-263. 2010. Available from: <http://dx.doi: 10.1016/j. vetmic.2009.12.029>. Accessed: Aug. 2010. doi: 10.1016/j. vetmic.2009.12.029.

LIU, H. J. et al. The lichen genus Kroswia in China. Mycotaxon, v.130, n.4, p.951-959. 2015. Available from: <http:// dx.doi: 10.5248/130.951>. Accessed: Oct-Dec. 2015. doi: $10.5248 / 130.951$

LIU, J. et al. Phytochrome B control of total leaf area and stomatal density affects drought tolerance in rice. Plant Molecular Biology, v.78, n.3, p.289-300. 2012. Available from: <http:// dx.doi: 10.1007/s11103-011-9860-3>. Accessed: Feb. 2012. doi: 10.1007/s11103-011-9860-3.

LIU, M. et al. Use of animal models for the imaging and quantification of angiogenesis. Exp Anim. 2017. Available from: $<$ http://dx.doi: 10.1538/expanim.17-0054>. Accessed: Jul. 31, 2017. doi: 10.1538/expanim.17-0054.

LIU, T. T.; YAN, J. H. Review of the Palearctic Atemelia Herrich-Schaffer (Lepidoptera, Yponomeutoidea, Praydidae), with description of a new leafmining species. Zootaxa, v.4250, n.4, p.327-336. 2017. Available from: <http://dx.doi: 10.11646/ zootaxa.4250.4.3>. Accessed: Apr. 2017. doi: 10.11646/ zootaxa.4250.4.3.

LIU, W. et al. Protein Kinase LTRPK1 Influences Cold Adaptation and Microtubule Stability in Rice. Journal Of Plant Growth Regulation, v.32, n.3, p.483-490. 2013. Available from: <http:// dx.doi: 10.1007/s00344-012-9314-4>. Accessed: Sep. 2013. doi: $10.1007 / \mathrm{s} 00344-012-9314-4$.

LIU, X. X. et al. The involvement of TsFtsH8 in Thellungiella salsuginea tolerance to cold and high light stresses. Acta 
Physiologiae Plantarum, v.38, n.3. 2016. Available from: <http:// dx.doi: 10.1007/s11738-016-2080-3>. Accessed: Mar. 2016. doi: $10.1007 / \mathrm{s} 11738-016-2080-3$.

LLOP, E. et al. The use of lichen functional groups as indicators of air quality in a Mediterranean urban environment. Ecological Indicators, v.13, n.1, p.215-221. 2012. Available from: <http:// dx.doi: 10.1016/j.ecolind.2011.06.005>. Accessed: 2012. doi: 10.1016/j.ecolind.2011.06.005.

LOBELL, D. B. et al. Climate trends and global crop production since 1980. Science, v.333, n.6042, p.616-620. 2011. Available from: <http://dx.doi: 2011. doi.

LOU, M. F. et al. Effects of dietary fiber content on energetics in nonreproductive and reproductive Brandt's voles (Lasiopodomys brandtii). Canadian Journal Of Zoology, v.93, n.4, p.251-258 2015. Available from: <http://dx.doi: 10.1139/cjz-2014-0243>. Accessed: Apr. 2015. doi: 10.1139/cjz-2014-0243.

LU, L. et al. New and noteworthy species of the lichen genus Lecanora (Ascomycota; Lecanoraceae) from South Korea. Lichenologist, v.43, p.321-329. 2011. Available from: <http:// dx.doi: 10.1017/s0024282911000144>. Accessed: Jul. 2011. doi: $10.1017 / \mathrm{s} 0024282911000144$.

LU, L. et al. Lecanora gansuensis sp nov (subfusca group) from China. Mycotaxon, v.123, p.285-287. 2013. Available from: $<$ http://dx.doi: 10.5248/123.285>. Accessed: Jan-Mar. 2013. doi: $10.5248 / 123.285$.

LU, L. et al. Lecanora subjaponica, a new lichen from China. Lichenologist, v.44, n.4, p.465-468. 2012. Available from: <http:// dx.doi: 10.1017/s002428291200014x>. Accessed: Jul. 2012. doi: $10.1017 / \mathrm{s} 002428291200014 x$.

LU, M. et al. AtCNGC2 is involved in jasmonic acid-induced calcium mobilization. Journal Of Experimental Botany, v.67, n.3, p.809-819. 2016. Available from: <http://dx.doi: 10.1093/jxb/ erv500>. Accessed: Feb. 2016. doi: 10.1093/jxb/erv500.

LüCKING, R. et al. The 2016 classification of lichenized fungi in the Ascomycota and Basidiomycota - Approaching one thousand genera. Bryologist, v.119, n.4, p.361-416. 2017. Available from: $<$ http://dx.doi: 2017. doi.

MA, R. et al. A new species of Phlyctis (Phlyctidaceae) from China. Mycotaxon, v.114, p.361-366. 2010. Available from: $<$ http://dx.doi: 10.5248/114.361>. Accessed: Oct-Dec. 2010. doi: $10.5248 / 114.361$

MARTINY, J. B. H. et al. Microbial biogeography: putting microorganisms on the map. Nature Reviews Microbiology, v.4, n.2, p.102-112. 2006. Available from: <http://dx.doi: 2006. doi.

MAY, R. M. How Many Species are There on Earth? Science, v.241, n.4872, p.1441-1449. 1988. Available from: <http://dx.doi: 1988. doi.

MCCANN, K. S. The diversity-stability debate. Nature, v.405, n.6783, p.228-33. 2000. Available from: <http:// dx.doi: 10.1038/35012234>. Accessed: May, 11, 2000. doi: $10.1038 / 35012234$.

MENG, X. et al. Physiological changes in fruit ripening caused by overexpression of tomato S1AN2, an R2R3-MYB factor. Plant
Physiology And Biochemistry, v.89, p.24-30. 2015. Available from: <http://dx.doi: 10.1016/j.plaphy.2015.02.005>. Accessed: Apr. 2015. doi: 10.1016/j.plaphy.2015.02.005.

MENG, X. Q. et al. Subcellular localization of proline-rich tyrosine kinase 2 during oocyte fertilization and early-embryo development in mice. Journal Of Reproduction And Development, v.62, n.4, p.351-358. 2016. Available from: <http://dx.doi: Aug. 2016. doi.

NAEEM, S. et al. Declining biodiversity can alter the performance of ecosystems. Nature, v.368, n.6473, p.734-737. 1994. Available from: <http://dx.doi: 04/21/print, 1994. doi.

PANG, C. H. et al. Overexpression of SsCHLAPXs confers protection against oxidative stress induced by high light in transgenic Arabidopsis thaliana. Physiologia Plantarum, v.143, n.4, p.355-366. 2011. Available from: <http://dx.doi: 10.1111/j.1399-3054.2011.01515.x>. Accessed: Dec. 2011. doi: 10.1111/j.1399-3054.2011.01515.x.

PIMM, S. L.; BROWN, J. H. Ecology. Domains of diversity. Science, v.304, n.5672, p.831-3. 2004. Available from: <http:// dx.doi: 2004. doi.

PINCUS, Z. et al. MicroRNA predictors of longevity in Caenorhabditis elegans. PLoS Genet, v.7, n.9, p.e1002306. 2011. Available from: <http://dx.doi: 10.1371/journal.pgen.1002306>. Accessed: Sep. 2011. doi: 10.1371/journal.pgen.1002306.

PIRES, M. Watershed protection for a world city: the case of New York. Land Use Policy, v.21, n.2, p.161-175. 2004. Available from: <http://dx.doi: 2004. doi.

PLOUFFE, D. A. et al. Comparison of select innate immune mechanisms of fish and mammals. Xenotransplantation, v.12, n.4, p.266-77. 2005. Available from: <http://dx.doi: 10.1111/j.13993089.2005.00227.x>. Accessed: Jul. 2005. doi: 10.1111/j.13993089.2005.00227.x.

PRIMACK, R. B. Essentials of Conservation Biology. 4th Edition. Sinauer Associates, xii +585 p.,. 2006. Available from: <http:// dx.doi: doi:10.1111/j.1523-1739.1989.tb00213.x>. Accessed: 2006. doi: doi:10.1111/j.1523-1739.1989.tb00213.x.

PROSSER, J. I. Molecular and functional diversity in soil microorganisms. Plant \& Soil, v.244, n.1/2, p.9-17. 2002. Available from: <http://dx.doi: 2002. doi.

QI, Y.C. et al. Overexpression of suadea salsa S-adenosylmethionine synthetase gene promotes salt tolerance in transgenic tobacco. Acta Physiologiae Plantarum, v.32, n.2, p.263-269. 2010. Available from: <http://dx.doi: 10.1007/s11738-009-0403-3>. Accessed: Mar. 2010. doi: 10.1007/s11738-009-0403-3.

REED, D. H.; FRANKHAM, R. Correlation between Fitness and Genetic Diversity. Conservation Biology, v.17, n.1, p.230-237. 2003. Available from: $<$ http://dx.doi: 2003. doi.

REN, Q. Pertusaria albiglobosa, a new lichen from China Mycotaxon, v.124, p.349-352. 2013. Available from: <http:// dx.doi: 10.5248/124.349>. Accessed: Apr-Jun. 2013. doi: $10.5248 / 124.349$

REN, Q. New species of Pertusaria from China. Telopea, v.16, p.133-140. 2014. Available from: <http://dx.doi: 
10.7751/telopea20147851>. Accessed: 2014. doi: 10.7751/ telopea20147851.

REN, Q. A new species and new records of the lichen genus Pertusaria from China. Mycotaxon, v.130, n.3, p.689-693. 2015. Available from: $<\mathrm{http}: / / \mathrm{dx}$.doi: $10.5248 / 130.689>$. Accessed: JulSep. 2015. doi: 10.5248/130.689.

REN, Q. A revision of the lichen genus Ochrolechia in China. Lichenologist, v.49, n.1, p.67-84. 2017. Available from: <http:// dx.doi: 10.1017/s0024282916000529>. Accessed: Jan. 2017. doi: $10.1017 / \mathrm{s} 0024282916000529$.

REN, Q.; KOU, X. R. A new species of Pertusaria from China. Lichenologist, v.45, n.3, p.337-339. 2013. Available from: $<$ http:// dx.doi: 10.1017/s0024282913000066>. Accessed: May, 2013. doi: $10.1017 / \mathrm{s} 0024282913000066$.

REN, Q.; ZHAO, N. New taxa of the lichen genus Pertusaria from China. Mycotaxon, v.127, p.221-226. 2014. Available from: <http://dx.doi: 10.5248/127.221>. Accessed: Jan-Mar. 2014. doi: 10.5248/127.221.

REN, X. L. et al. Calcineurin B-like protein CBL10 directly interacts with AKT1 and modulates K+ homeostasis in Arabidopsis. Plant Journal, v.74, n.2, p.258-266. 2013. Available from: <http:// dx.doi: 10.1111/tpj.12123>. Accessed: Apr. 2013. doi: 10.1111/ tpj.12123.

ROMBOUT, J. et al. Adaptive immune responses at mucosal surfaces of teleost fish. Fish \& Shellfish Immunology, v.40, n.2, p.634-643. 2014. Available from: <http://dx.doi: 10.1016/j. fsi.2014.08.020>. Accessed: Oct. 2014. doi: 10.1016/j. fsi.2014.08.020.

SCHILD-PRUFERT, K. et al. Organization of the synaptonemal complex during meiosis in Caenorhabditis elegans. Genetics, v.189, n.2, p.411-21. 2011. Available from: <http://dx.doi: 10.1534/genetics.111.132431>. Accessed: Oct. 2011. doi: 10.1534/ genetics.111.132431.

SCHNEIDER, F. D. et al. Animal diversity and ecosystem functioning in dynamic food webs. Nature Communications, v.7, p.12718. 2016. Available from: <http://dx.doi: 2016. doi.

SHAN, S. et al. Non-mammalian Toll-like receptor 18 (Tlr18) recognizes bacterial pathogens in common carp (Cyprinus carpio $L$.): Indications for a role of participation in the NF-kappaB signaling pathway. Fish Shellfish Immunol, v.72, p.187-198. 2018. Available from: <http://dx.doi: 10.1016/j.fsi.2017.09.081> Accessed: Oct. 27, 2018. doi: 10.1016/j.fsi.2017.09.081.

SHAN, S. J. et al. Identification and expression analysis of irak1 gene in common carp Cyprinus carpio L.: indications for a role of antibacterial and antiviral immunity. Journal Of Fish Biology, v.87, n.2, p.241-255. 2015. Available from: $<$ http://dx.doi: 10.1111/ jfb.12714>. Accessed: Aug. 2015. doi: 10.1111/jfb.12714.

SHAO, Q. et al. SsHKT1;1 is a potassium transporter of the C-3 halophyte Suaeda salsa that is involved in salt tolerance. Functional Plant Biology, v.41, n.8, p.790-802. 2014. Available from: <http://dx.doi: 10.1071/fp13265>. Accessed: 2014. doi: 10.1071/fp13265.

SHEN, X. Y. et al. Transcriptomic profiling revealed an important role of cell wall remodeling and ethylene signaling pathway during salt acclimation in Arabidopsis. Plant Molecular Biology, v.86, n.3, p.303-317. 2014. Available from: <http://dx.doi: 10.1007/ s11103-014-0230-9>. Accessed: Oct. 2014. doi: 10.1007/s11103014-0230-9.

SMOLIKOV, S. et al. A yeast two-hybrid screen for SYP-3 interactors identifies SYP-4, a component required for synaptonemal complex assembly and chiasma formation in Caenorhabditis elegans meiosis. PLoS Genet, v.5, n.10, p.e1000669. 2009. Available from: <http://dx.doi: 10.1371/journal.pgen.1000669>. Accessed: Oct. 2009. doi: 10.1371/journal.pgen.1000669.

SONG, J. et al. Waterlogging and salinity effects on two Suaeda salsa populations. Physiologia Plantarum, v.141, n.4, p.343351. 2011. Available from: <http://dx.doi: 10.1111/j.13993054.2011.01445.x>. Accessed: Apr. 2011. doi: 10.1111/j.13993054.2011.01445.x.

SONG, J. et al. The role of the seed coat in adaptation of dimorphic seeds of the euhalophyte Suaeda salsa to salinity. Plant Species Biology, v.32, n.2, p.107-114. 2017. Available from: <http:// dx.doi: 10.1111/1442-1984.12132>. Accessed: Apr. 2017. doi: 10.1111/1442-1984.12132.

SONG, J.; WANG, B. S. Using euhalophytes to understand salt tolerance and to develop saline agriculture: Suaeda salsa as a promising model. Annals Of Botany, v.115, n.3, p.541-553. 2015. Available from: <http://dx.doi: 10.1093/aob/mcu194>. Accessed: Feb. 2015. doi: 10.1093/aob/mcu194.

SONG, J. et al. Effects of salinity and nitrate on production and germination of dimorphic seeds applied both through the mother plant and exogenously during germination in Suaeda salsa. Plant Species Biology, v.31, n.1, p.19-28. 2016. Available from: <http:// dx.doi: 10.1111/1442-1984.12071>. Accessed: Jan. 2016. doi: 10.1111/1442-1984.12071.

SUI, N. Photoinhibition of Suaeda salsa to chilling stress is related to energy dissipation and water-water cycle. Photosynthetica, v.53, n.2, p.207-212. 2015. Available from: <http://dx.doi: 10.1007/s11099-015-0080-y>. Accessed: Jun. 2015. doi: 10.1007/ s11099-015-0080-y.

SUI, N.; HAN, G. L. Salt-induced photoinhibition of PSII is alleviated in halophyte Thellungiella halophila by increases of unsaturated fatty acids in membrane lipids. Acta Physiologiae Plantarum, v.36, n.4, p.983-992. 2014. Available from: <http:// dx.doi: 10.1007/s11738-013-1477-5>. Accessed: Apr. 2014. doi: 10.1007/s11738-013-1477-5.

SUI, N. et al. Increase in unsaturated fatty acids in membrane lipids of Suaeda salsa L. enhances protection of photosystem II under high salinity. Photosynthetica, v.48, n.4, p.623-629. 2010. Available from: <http://dx.doi: 10.1007/s11099-010-0080-x>. Accessed: Dec. 2010. doi: 10.1007/s11099-010-0080-x.

SUN, G. J. et al. Molecular cloning and expression analysis of P-selectin glycoprotein ligand-1 from zebrafish (Danio rerio). Fish Physiology And Biochemistry, v.38, n.2, p.555-564. 2012. Available from: <http://dx.doi: 10.1007/s10695-011-9535-7>. Accessed: Apr. 2012. doi: 10.1007/s10695-011-9535-7.

SUN, L. Y. et al. A new lichen, Melanohalea subexasperata (Parmeliaceae), from the Tibetan Plateau. Mycotaxon, v.111, p.65-69. 2010. Available from: <http://dx.doi: 10.5248/111.65>. Accessed: Jan-Mar. 2010. doi: 10.5248/111.65. 
SUN, W. et al. The TsnsLTP4, a Nonspecific Lipid Transfer Protein Involved in Wax Deposition and Stress Tolerance. Plant Molecular Biology Reporter, v.33, n.4, p.962-974. 2015. Available from: $<$ http://dx.doi: 10.1007/s11105-014-0798-x>. Accessed: Aug. 2015. doi: 10.1007/s11105-014-0798-x.

SUN, Z. B. et al. Overexpression of TsGOLS2, a galactinol synthase, in Arabidopsis thaliana enhances tolerance to high salinity and osmotic stresses. Plant Physiology And Biochemistry, v.69, p.82-89. 2013. Available from: <http://dx.doi: 10.1016/j. plaphy.2013.04.009>. Accessed: Aug. 2013. doi: 10.1016/j. plaphy.2013.04.009.

TANG, G. Y. et al. Ectopic expression of peanut acyl carrier protein in tobacco alters fatty acid composition in the leaf and resistance to cold stress. Biologia Plantarum, v.56, n.3, p.493-501. 2012. Available from: <http://dx.doi: 10.1007/s10535-012-0057-7> Accessed: Sep. 2012. doi: 10.1007/s10535-012-0057-7.

TIAN, Q. et al. A new species of Nephroma (Nephromataceae) from the Tibetan Plateau. Mycotaxon, v.115, p.281-285. 2011. Available from: <http://dx.doi: 10.5248/115.281 >. Accessed: JanMar. 2011. doi: 10.5248/115.281.

TILMAN, D. Biodiversity: Population Versus Ecosystem Stability. Ecology, v.77, n.2, p.350-363. 1996. Available from: <http:// dx.doi: 1996. doi.

WANG, C. M. et al. A new species of free-living marine nematode (Nematoda: Chromadoridae) from the East China Sea. Zootaxa, v.3947, n.2, p.289-295. 2015a. Available from: <http://dx.doi: 10.11646/zootaxa.3947.2.11>. Accessed: Apr. 2015a. doi: 10.11646/zootaxa.3947.2.11.

WANG, C. M. et al. Two new species of Terschellingia (Nematoda: Monhysterida: Linhomoeidae) from the East China Sea. Cahiers De Biologie Marine, v.58, n.1, p.33-41. 2017a. Available from: <http://dx.doi: 10.21411/cbm.a.cbb42ea>. Accessed: 2017a. doi: 10.21411/cbm.a.cbb42ea

WANG, F. et al. Study on the Hemolysin Phenotype and the Genetype Distribution of Staphyloccocus aureus Caused Bovine Mastitis in Shandong Dairy Farms. International Journal Of Applied Research In Veterinary Medicine, v.9, n.4, p.416-421. 2011. Available from: $<$ http://dx.doi: 2011. doi.

WANG, F. R. et al. Genetic dissection of the introgressive genomic components from Gossypium barbadense $L$. that contribute to improved fiber quality in Gossypium hirsutum L. Molecular Breeding, v.32, n.3, p.547-562. 2013a. Available from: <http:// dx.doi: 10.1007/s11032-013-9888-y>. Accessed: Oct. 2013a. doi: 10.1007/s11032-013-9888-y.

WANG, F. X. et al. Salinity affects production and salt tolerance of dimorphic seeds of Suaeda salsa. Plant Physiology And Biochemistry, v.95, p.41-48. 2015b. Available from: <http:// dx.doi: 10.1016/j.plaphy.2015.07.005>. Accessed: Oct. 2015b. doi: 10.1016/j.plaphy.2015.07.005.

WANG, H. Y. et al. Additional information on Lecanora loekoesii. Mycotaxon, v.123, p.235-239. 2013b. Available from: <http:// dx.doi: 10.5248/123.235>. Accessed: Jan-Mar. 2013b. doi: 10.5248/123.235.

WANG, H. Y. et al. Five lichens of Leptogium new to China. Mycotaxon, v.111, p.161-166. 2010. Available from: <http:// dx.doi: 10.5248/111.161>. Accessed: Jan-Mar. 2010. doi: 10.5248/111.161.

WANG, J. S. et al. Genome-Wide Analysis of Gene Expression Provides New Insights into Cold Responses in Thellungiella salsuginea. Frontiers In Plant Science, v.8. 2017b. Available from: <http://dx.doi: 10.3389/fpls.2017.00713>. Accessed: May, 2017b. doi: $10.3389 /$ fpls.2017.00713.

WANG, P. F. et al. Genome-Wide Dissection of the Heat Shock Transcription Factor Family Genes in Arachis. Frontiers In Plant Science, v.8. 2017c. Available from: <http://dx.doi: 10.3389/fpls.2017.00106>. Accessed: Feb. 2017c. doi: 10.3389/ fpls.2017.00106.

WANG, S. S. et al. Transcript profiles of maize embryo sacs and preliminary identification of genes involved in the embryo sacpollen tube interaction. Frontiers In Plant Science, v.5. 2014a. Available from: <http://dx.doi: 10.3389/fpls.2014.00702>. Accessed: Dec. 2014a. doi: 10.3389/fpls.2014.00702.

WANG, W. C. et al. New records of Rhizocarpon from Hengduan Mountains, China. Mycotaxon, v.131, n.3, p.589-596. 2016. Available from: <http://dx.doi: 10.5248/131.589>. Accessed: JulSep. 2016. doi: 10.5248/131.589.

WANG, W. C. et al. Four Rhizocarpon species new to China. Mycotaxon, v.130, n.3, p.883-891. 2015c. Available from: $<$ http://dx.doi: 10.5248/130.883>. Accessed: Jul-Sep. 2015c. doi: $10.5248 / 130.883$.

WANG, X. G. et al. Regulatory mutations in the A2M gene are involved in the mastitis susceptibility in dairy cows. Animal Genetics, v.45, n.1, p.28-37. 2014b. Available from: <http:// dx.doi: 10.1111/age.12099>. Accessed: Feb. 2014b. doi: 10.1111/ age.12099.

WANG, X. Y. et al. New species and new records of the lichen genus Porpidia (Lecideaceae) from western China. Lichenologist, v.44, n.5, p.619-624. 2012. Available from: <http://dx.doi: 10.1017/ s0024282912000242>. Accessed: Sep. 2012. doi: 10.1017/ s0024282912000242.

WANG, Y. H. et al. Genetic diversity of wild soybean populations in Dongying, China, by simple sequence repeat analysis. Genet Mol Res, v.14, n.3, p.11613-23. 2015d. Available from: <http:// dx.doi: 10.4238/2015.September.28.13>. Accessed: Sep. 28, 2015d. doi: 10.4238/2015.September.28.13.

WASILKOWSKI, D. et al. Changes in Enzyme Activities and Microbial Community Structure in Heavy Metal-Contaminated Soil Under In Situ Aided Phytostabilization. CLEAN - Soil, Air, Water, v.42, n.11, p.1618-1625. 2015. Available from: <http:// dx.doi: 2015. doi.

WENG, L. et al. Petal Development in Lotus japonicus. Journal Of Integrative Plant Biology, v.53, n.10, p.770-782. 2011 Available from: $<$ http://dx.doi: 10.1111/j.1744-7909.2011.01072. $\mathrm{x}>$. Accessed: Oct. 2011. doi: 10.1111/j.1744-7909.2011.01072.x.

XIE, S. B.; ZHOU, J. Harnessing Plant Biodiversity for the Discovery of Novel Anticancer Drugs Targeting Microtubules. Frontiers In Plant Science, v.8. 2017. Available from: <http:// dx.doi: 10.3389/fpls.2017.00720>. Accessed: May, 2017. doi: 10.3389/fpls.2017.00720. 
XU, Y. G. et al. Changes in endogenous hormones and seed-coat phenolics during seed storage of two Suaeda salsa populations. Australian Journal Of Botany, v.64, n.4, p.325-332. 2016. Available from: <http://dx.doi: 10.1071/bt16014>. Accessed: 2016. doi: $10.1071 / \mathrm{bt} 16014$.

YANG, G. W. et al. Molecular characterization of LEAP-2 cDNA in common carp (Cyprinus carpio L.) and the differential expression upon a Vibrio anguillarum stimulus; indications for a significant immune role in skin. Fish \& Shellfish Immunology, v.37, n.1, p.22-29. 2014. Available from: <http://dx.doi: 10.1016/j.fsi.2014.01.004>. Accessed: Mar, 2014. doi: 10.1016/j. fsi.2014.01.004.

YANG, J. C. et al. DEFICIENCY OF PHYTOCHROME B ALLEVIATES CHILLING-INDUCED PHOTOINHIBITION IN RICE. American Journal Of Botany, v.100, n.9, p.1860-1870. 2013. Available from: <http://dx.doi: 10.3732/ajb.1200574>. Accessed: Sep. 2013. doi: 10.3732/ajb.1200574.

YANG, M. F. et al. Organ-Specific Responses of Vacuolar H+ATPase in the Shoots and Roots of C-3 Halophyte Suaeda salsa to $\mathrm{NaCl}$. Journal Of Integrative Plant Biology, v.52, n.3, p.308-314. 2010. Available from: <http://dx.doi: 10.1111/j.17447909.2010.00895.x>. Accessed: Mar. 2010. doi: 10.1111/j.1744 7909.2010.00895.x.

YANG, Y. et al. Effects of FSTL1 on the proliferation and motility of breast cancer cells and vascular endothelial cells. Thorac Cancer, v.8, n.6, p.606-612. 2017. Available from: <http:// dx.doi: 10.1111/1759-7714.12491>. Accessed: Nov. 2017. doi: $10.1111 / 1759-7714.12491$

YU, J. et al. Concurrent highly pathogenic porcine reproductive and respiratory syndrome virus infection accelerates Haemophilus parasuis infection in conventional pigs. Veterinary Microbiology, v.158, n.3-4, p.316-321. 2012. Available from: <http://dx.doi: 10.1016/j.vetmic.2012.03.001>. Accessed: Aug. 2012. doi: 10.1016/j.vetmic.2012.03.001

YU, S. B. et al. Importance of epistasis as the genetic basis of heterosis in an elite rice hybrid. Proc Natl Acad Sci U S A, v.94, n.17, p.9226-9231. 1997. Available from: <http://dx.doi: 1997. doi.

YUAN, C. et al. Austdiol, fulvic acid and citromycetin derivatives from an endolichenic fungus, Myxotrichum sp. Phytochemistry Letters, v.6, n.4, p.662-666. 2013a. Available from: <http://dx.doi: 10.1016/j.phytol.2013.08.011>. Accessed: Nov. 2013a. doi: 10.1016/j.phytol.2013.08.011.

YUAN, F. et al. An efficient autofluorescence method for screening Limonium bicolor mutants for abnormal salt gland density and salt secretion. South African Journal Of Botany, v.88, p.110-117. 2013b. Available from: <http://dx.doi: 10.1016/j. sajb.2013.06.007>. Accessed: Sep. 2013b. doi: 10.1016/j. sajb.2013.06.007.

YUAN, F. et al. A system for the transformation and regeneration of the recretohalophyte Limonium bicolor. In Vitro Cellular \& Developmental Biology-Plant, v.50, n.5, p.610-617. 2014. Available from: <http://dx.doi: 10.1007/s11627-014-9611-7>. Accessed: Oct. 2014. doi: 10.1007/s11627-014-9611-7.

YUAN, F. et al. THE OPTIMAL DOSAGE OF Co-60 GAMMA IRRADIATION FOR OBTAINING SALT GLAND MUTANTS OF EXO-RECRETOHALOPHYTE LIMONIUM BICOLOR
(BUNGE) O. KUNTZE. Pakistan Journal Of Botany, v.47, n.1, p.71-76. 2015a. Available from: $<$ http://dx.doi: Feb. 2015a. doi.

YUAN, F. et al. Reproductive Physiology of Halophytes: Current Standing. Frontiers in Plant Science, v.9, p.13. 2019. Available from: <http://dx.doi: 10.3389/fpls.2018.01954>. Accessed: Jan. 2019. doi: $10.3389 /$ fpls.2018.01954.

YUAN, F. et al. Progress in Studying Salt Secretion from the Salt Glands in Recretohalophytes: How Do Plants Secrete Salt? Frontiers In Plant Science, v.7. 2016a. Available from: <http:// dx.doi: 10.3389/fpls.2016.00977>. Accessed: Jun. 2016a. doi: $10.3389 /$ fpls.2016.00977.

YUAN, F. et al. Comparative transcriptome analysis of developmental stages of the Limonium bicolor leaf generates insights into salt gland differentiation. Plant Cell And Environment, v.38, n.8, p.1637-1657. 2015b. Available from: $<$ http://dx.doi: 10.1111/pce.12514>. Accessed: Aug. 2015b. doi: 10.1111/pce.12514.

YUAN, F. et al. The transcriptome of NaCl-treated Limonium bicolor leaves reveals the genes controlling salt secretion of salt gland. Plant Molecular Biology, v.91, n.3, p.241-256. 2016 b. Available from: <http://dx.doi: 10.1007/s11103-016-0460-0>. Accessed: Jun. 2016b. doi: 10.1007/s11103-016-0460-0.

ZHANG, F. et al. Pseudomonas reactans, a Bacterial Strain Isolated From the Intestinal Flora of Blattella germanica With AntiBeauveria bassiana Activity. Environmental Entomology, v.42, n.3, p.453-459. 2013a. Available from: <http://dx.doi: 10.1603/ en12347>. Accessed: Jun. 2013a. doi: 10.1603/en12347.

ZHANG, F. et al. Differential Expression of Hemolymph Proteins Between Susceptible and Insecticide-Resistant Blattella germanica (Blattodea: Blattellidae). Environmental Entomology, v.43, n.4, p.1117-1123. 2014. Available from: <http://dx.doi: 10.1603/ en13351>. Accessed: Aug. 2014. doi: 10.1603/en13351.

ZHANG, H. Y. et al. Golgi Apparatus-Localized Synaptotagmin 2 Is Required for Unconventional Secretion in Arabidopsis. Plos One, v.6, n.11. 2011. Available from: <http://dx.doi: $10.1371 /$ journal.pone.0026477>. Accessed: Nov. 2011. doi: 10.1371/ journal.pone.0026477.

ZHANG, J. X. et al. The role of arabidopsis AtFes1A in cytosolic Hsp70 stability and abiotic stress tolerance. Plant Journal, v.62, n.4, p.539-548. 2010a. Available from: <http://dx.doi: 10.1111/j.1365-313X.2010.04173.x>. Accessed: May, 2010a. doi: 10.1111/j.1365-313X.2010.04173.x.

ZHANG, L. L. et al. New records of Clauzadea and Immersaria from China. Mycotaxon, v.130, n.3, p.899-905. 2015a. Available from: <http://dx.doi: 10.5248/130.899>. Accessed: Jul-Sep. 2015a. doi: $10.5248 / 130.899$

ZHANG, L. L. et al. Four lichens of the genus Lecidea from China. Mycotaxon, v.112, p.445-450. 2010b. Available from: $<$ http://dx.doi: 10.5248/112.445>. Accessed: Apr-Jun. 2010b. doi: $10.5248 / 112.445$.

ZHANG, L. L. et al. Four new records of lecideoid lichens from China. Mycotaxon, v.119, p.445-451. 2012. Available from: $<$ http://dx.doi: 10.5248/119.445>. Accessed: Jan-Mar. 2012. doi: $10.5248 / 119.445$ 
ZHANG, L. L. et al. New records of one Amygdalaria and three Porpidia taxa (Lecideaceae) from China. Mycotaxon, v.130, n.1, p.33-40. 2015b. Available from: <http://dx.doi: 10.5248/130.33>. Accessed: Jan-Mar. 2015b. doi: 10.5248/130.33.

ZHANG, L. Y. et al. Meta-analysis of salt-related gene expression profiles identifies common signatures of salt stress responses in Arabidopsis. Plant Systematics And Evolution, v.303, n.6, p.757774. 2017a. Available from: <http://dx.doi: 10.1007/s00606-0171407-x>. Accessed: Jun. 2017a. doi: 10.1007/s00606-017-1407-x.

ZHANG, Q. et al. Genome-wide identification of Thellungiella salsuginea microRNAs with putative roles in the salt stress response. Bmc Plant Biology, v.13. 2013b. Available from: $<$ http:/ dx.doi: 10.1186/1471-2229-13-180>. Accessed: Nov. 2013b. doi: 10.1186/1471-2229-13-180.

ZHANG, S. R. et al. Effect of salinity on seed germination, ion content and photosynthesis of cotyledons in halophytes or xerophyte growing in Central Asia. Journal Of Plant Ecology, v.3, n.4, p.259-267. 2010c. Available from: <http://dx.doi: 10.1093/jpe/ rtq005>. Accessed: Dec. 2010c. doi: 10.1093/jpe/rtq005.

ZHANG, X. Y. et al. A Maternal Low-Fiber Diet Predisposes Offspring to Improved Metabolic Phenotypes in Adulthood in an Herbivorous Rodent. Physiological And Biochemical Zoology, v.90, n.1, p.75-84. 2017b. Available from: <http:// dx.doi: 10.1086/688978>. Accessed: Jan-Feb. 2017b. doi: $10.1086 / 688978$.

ZHANG, Y. H. et al. Reduced function of the RNA-binding protein FPA rescues a T-DNA insertion mutant in the Arabidopsis ZHOUPI gene by promoting transcriptional read-through. Plant Molecular Biology, v.91, n.4-5, p.549-561. 2016. Available from: <http:// dx.doi: 10.1007/s11103-016-0487-2>. Accessed: Jul. 2016. doi: $10.1007 / \mathrm{s} 11103-016-0487-2$

ZHANG, Z.; LI, H. Biological study of Epicephala assamica (Lepidoptera: Gracilariidae) with notes on morphology of immature stages. Journal of Asia-Pacific Entomology, v.20, n.3, p.918-927. 2017. Available from: <http://dx.doi: 10.1016/j.aspen.2017.05.003>. Accessed: 2017. doi: 10.1016/j. aspen.2017.05.003

ZHAO, B. T. et al. Arabidopsis KLU homologue GmCYP78A72 regulates seed size in soybean. Plant Molecular Biology, v.90, n.1-2, p.33-47. 2016a. Available from: <http://dx.doi: 10.1007/ s11103-015-0392-0>. Accessed: Jan. 2016a. doi: 10.1007/s11103015-0392-0.

ZHAO, B. T. et al. Effect of brassinosteroids on ammonium uptake via regulation of ammonium transporter and N-metabolism genes in Arabidopsis. Biologia Plantarum, v.60, n.3, p.563-571. 2016b. Available from: <http://dx.doi: 10.1007/s10535-016-0627-1>. Accessed: Sep. 2016b. doi: 10.1007/s10535-016-0627-1.

ZHAO, K. F. et al. Growth Response to Ionic and Osmotic Stress of $\mathrm{NaCl}$ in Salt-tolerant and Salt-sensitive Maize. Journal Of Integrative Plant Biology, v.52, n.5, p.468-475. 2010a. Available from: $\quad<$ http://dx.doi: $10.1111 /$ j.1744-7909.2010.00947.x>. Accessed: May, 2010a. doi: 10.1111/j.1744-7909.2010.00947.x.

ZHAO, L. et al. An Improved CTAB-Ammonium Acetate Method for Total RNA Isolation from Cotton. Phytochemical Analysis, v.23, n.6, p.647-650. 2012. Available from: <http://dx.doi: 10.1002/ pca.2368>. Accessed: Nov-Dec. 2012. doi: 10.1002/pca.2368.
ZHAO, S. S. et al. CASEIN KINASE1-LIKE PROTEIN2 Regulates Actin Filament Stability and Stomatal Closure via Phosphorylation of Actin Depolymerizing Factor. Plant Cell, v.28, n.6, p.1422-1439. 2016c. Available from: <http://dx.doi: 10.1105/ tpc. 16.00078>. Accessed: Jun. 2016c. doi: 10.1105/tpc.16.00078.

ZHAO, S. Z. et al. Light-regulated betacyanin accumulation in euhalophyte Suaeda salsa calli. Plant Cell Tissue And Organ Culture, v.102, n.1, p.99-107. 2010b. Available from: <http:// dx.doi: 10.1007/s11240-010-9710-z>. Accessed: Jul. 2010b. doi: $10.1007 / \mathrm{s} 11240-010-9710-\mathrm{z}$.

ZHAO, S. Z. et al. Growth regulator-induced betacyanin accumulation and dopa-4,5-dioxygenase (DODA) gene expression in euhalophyte Suaeda salsa calli. In Vitro Cellular \& Developmental Biology-Plant, v.47, n.3, p.391-398. 2011a. Available from: <http://dx.doi: 10.1007/s11627-011-9339-6>. Accessed: Jun. 2011a. doi: 10.1007/s11627-011-9339-6.

ZHAO, X. et al. Using multi-locus sequence data for addressing species boundaries in commonly accepted lichen-forming fungal species. Organisms Diversity \& Evolution, v.17, n.2, p.351-363. 2017. Available from: <http://dx.doi: 10.1007/s13127-016-03204>. Accessed: Jun. 2017. doi: 10.1007/s13127-016-0320-4.

ZHAO, X. et al. Towards a revised generic classification of lecanoroid lichens (Lecanoraceae, Ascomycota) based on molecular, morphological and chemical evidence. Fungal Diversity, v.78, n.1, p.293-304. 2016d. Available from: <http:// dx.doi: 10.1007/s13225-015-0354-5>. Accessed: May, 2016d. doi: $10.1007 / \mathrm{s} 13225-015-0354-5$.

ZHAO, X. et al. A new species of Miriquidica from China Mycotaxon, v.123, p.363-367. 2013a. Available from: <http:// dx.doi: 10.5248/123.363>. Accessed: Jan-Mar. 2013a. doi: $10.5248 / 123.363$.

ZHAO, X. et al. A Molecular Phylogeny of the Lichen Genus Lecidella Focusing on Species from Mainland China. Plos One, v.10, n.9. 2015. Available from: <http://dx.doi: 10.1371/journal. pone.0139405>. Accessed: Sep. 2015. doi: 10.1371/journal. pone. 0139405 .

ZHAO, X. X. et al. A new species of Porpidia from China. Lichenologist, v.48, n.3, p.229-235. 2016e. Available from: $<$ http://dx.doi: 10.1017/s0024282916000128>. Accessed: May, 2016e. doi: 10.1017/s0024282916000128.

ZHAO, X. Y. et al. Climatic information recorded in stable carbon isotopes in tree rings of Cryptomeria fortunei, Tianmu Mountain, China. Dendrochronologia, v.32, n.3, p.256-265. 2014a. Available from: <http://dx.doi: 10.1016/j.dendro.2014.06.002>. Accessed: 2014a. doi: 10.1016/j.dendro.2014.06.002.

ZHAO, Y. et al. The Plant-Specific Actin Binding Protein SCAB1 Stabilizes Actin Filaments and Regulates Stomatal Movement in Arabidopsis. Plant Cell, v.23, n.6, p.2314-2330. 2011b. Available from: <http://dx.doi: 10.1105/tpc.111.086546>. Accessed: Jun. 2011b. doi: $10.1105 /$ tpc. 111.086546 .

ZHAO, Z. T. et al. New records of Rhizocarpon from China. Mycotaxon, v.125, p.217-226. 2013b. Available from: <http:// dx.doi: 10.5248/125.217>. Accessed: Jul-Sep. 2013b. doi: $10.5248 / 125.217$

ZHAO, Z. T. et al. Pertusaria yunnana, a new species from southwest China. Lichenologist, v.46, n.2, p.169-173. 2014b. Available 
from: <http://dx.doi: 10.1017/s0024282913000881>. Accessed: Mar. 2014b. doi: 10.1017/s0024282913000881.

ZHENG, Y. et al. The Glycosyltransferase QUA1 Regulates Chloroplast-Associated Calcium Signaling During Salt and Drought Stress in Arabidopsis. Plant And Cell Physiology, v.58, n.2, p.329-341. 2017. Available from: <http://dx.doi: 10.1093/pcp/ pcw192>. Accessed: Feb. 2017. doi: 10.1093/pcp/pcw192.

ZHOU, G. L. et al. Seven dark fruiting lichens of Caloplaca from China. Mycotaxon, v.122, p.307-324. 2012. Available from: $<$ http://dx.doi: 10.5248/122.307>. Accessed: Oct-Dec. 2012. doi: 10.5248/122.307.

ZHOU, J. C. et al. The role of salinity in seed maturation of the euhalophyte Suaeda salsa. Plant Biosystems, v.150, n.1, p.83-90. 2016. Available from: <http://dx.doi: 10.1080/11263504.2014.976294>. Accessed: Jan. 2016. doi: $10.1080 / 11263504.2014 .976294$.

ZHOU, J. C. et al. The role of cotyledons in the establishment of Suaeda physophora seedlings. Plant Biosystems, v.148, n.4, p.584-590. 2014a. Available from: <http://dx.doi:
10.1080/11263504.2013.788574>. Accessed: Jul. 2014a. doi: $10.1080 / 11263504.2013 .788574$.

ZHOU, J. J. et al. Overexpression of OsPIL15, a phytochromeinteracting factor- like protein gene, represses etiolated seedling growth in rice. Journal Of Integrative Plant Biology, v.56, n.4, p.373-387. 2014b. Available from: <http:// dx.doi: 10.1111/jipb.12137>. Accessed: Apr. 2014b. doi: 10.1111/jipb.12137.

ZHU, Q. L. et al. The phospholipase C (FgPLC1) is involved in regulation of development, pathogenicity, and stress responses in Fusarium graminearum. Fungal Genetics And Biology, v.97, p.1-9. 2016a. Available from: <http://dx.doi: 10.1016/j. fgb.2016.10.004>. Accessed: Dec. 2016a. doi: 10.1016/j. fgb.2016.10.004.

ZHU, Y. Y. et al. Characterization and immune response expression of the Rig-I-like receptor mda5 in common carp Cyprinus carpio. Journal Of Fish Biology, v.88, n.6, p.2188-2202. 2016b. Available from: <http://dx.doi: 10.1111/jfb.12981>. Accessed: Jun. 2016 b. doi: $10.1111 / \mathrm{jfb} .12981$. 